\title{
Front Matter: Volume 9990
}

, "Front Matter: Volume 9990," Proc. SPIE 9990, High-Power Lasers 2016: Technology and Systems, 999001 (27 December 2016); doi: $10.1117 / 12.2264059$

SPIE. Event: SPIE Security + Defence, 2016, Edinburgh, United Kingdom 


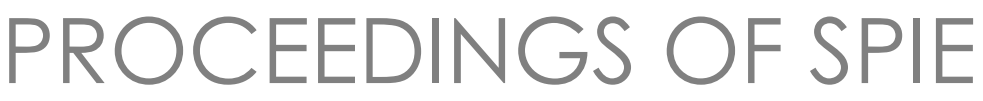

\title{
High-Power Lasers 2016: Technology and Systems
}

\author{
Harro Ackermann \\ Willy L. Bohn \\ David H. Titterton \\ Editors
}

28-29 September 2016

Edinburgh, United Kingdom

Sponsored by

SPIE

Cooperating Organisations

Innovation Centre for Sensor and Imaging Systems (United Kingdom)

ADS Scotland (United Kingdom)

The Knowledge Transfer Network (United Kingdom)

Visit Scotland (United Kingdom)

European Regional Development Fund (Belgium)

Technology Scotland (United Kingdom)

Published by

SPIE 
The papers in this volume were part of the technical conference cited on the cover and title page. Papers were selected and subject to review by the editors and conference program committee. Some conference presentations may not be available for publication. Additional papers and presentation recordings may be available online in the SPIE Digital Library at SPIEDigitallibrary.org.

The papers reflect the work and thoughts of the authors and are published herein as submitted. The publisher is not responsible for the validity of the information or for any outcomes resulting from reliance thereon.

Please use the following format to cite material from these proceedings:

Author(s), "Title of Paper," in High-Power Lasers 2016: Technology and Systems, edited by Harro Ackermann, Willy L. Bohn, David H. Titterton, Proceedings of SPIE Vol. 9990 (SPIE, Bellingham, WA, 2016) six-digit Article CID Number.

ISSN: 0277-786X

ISSN:1996-756X (electronic)

ISBN: 9781510603844

ISBN: 9781510603851 (electronic)

Published by

SPIE

P.O. Box 10, Bellingham, Washington 98227-0010 USA

Telephone +1 3606763290 (Pacific Time) · Fax +1 3606471445

SPIE.org

Copyright (C) 2016, Society of Photo-Optical Instrumentation Engineers.

Copying of material in this book for internal or personal use, or for the internal or personal use of specific clients, beyond the fair use provisions granted by the U.S. Copyright Law is authorized by SPIE subject to payment of copying fees. The Transactional Reporting Service base fee for this volume is $\$ 18.00$ per article (or portion thereof), which should be paid directly to the Copyright Clearance Center (CCC), 222 Rosewood Drive, Danvers, MA 01923. Payment may also be made electronically through CCC Online at copyright.com. Other copying for republication, resale, advertising or promotion, or any form of systematic or multiple reproduction of any material in this book is prohibited except with permission in writing from the publisher. The CCC fee code is 0277-786X/16/\$18.00.

Printed in the United States of America.

Publication of record for individual papers is online in the SPIE Digital Library.

\section{SPIE. DIGITAL \\ SPIEDigitallibrary.org}

Paper Numbering: Proceedings of SPIE follow an e-First publication model. A unique citation identifier (CID) number is assigned to each article at the time of publication. Utilization of CIDs allows articles to be fully citable as soon as they are published online, and connects the same identifier to all online and print versions of the publication. SPIE uses a six-digit CID article numbering system structured as follows:

- $\quad$ The first four digits correspond to the SPIE volume number.

- $\quad$ The last two digits indicate publication order within the volume using a Base 36 numbering system employing both numerals and letters. These two-number sets start with $00,01,02,03,04,05,06,07,08,09,0 A, 0 B \ldots$. 0Z, followed by 10-1Z, 20-2Z, etc. The CID Number appears on each page of the manuscript. 


\title{
Contents
}

\author{
$\checkmark$ Authors \\ vii Conference Committee
}

\section{NOVEL LASER SYSTEMS AND POWER SCALING}

999003 Investigation on scalable high-power lasers with enhanced 'eye-safety' for future weapon systems (Invited Paper) [9990-2]

DIODE PUMPED ALKALI LASERS AND OTHER ADVANCED GAS LASERS

9990 OC Thermal effects in Cs DPAL and alkali cell window damage (Invited Paper) [9990-8]

9990 OD Comparative study of DPAL and XPAL systems and selection principal of parameters [9990-9]

$9990 \mathrm{OE}$ Conceptual design of a space-based $\mathrm{O}_{2}$ laser for defense [9990-10]

$9990 \mathrm{OF}$ Experimental and theoretical study of the performance of optically pumped cesium vapor laser as a function of the pump-to-laser beam overlap [9990-18]

\section{LASER INTERACTION AND DAMAGE}

9990 OG Study on the laser irradiation effects on coating reinforced glass fiber/resin composite material [9990-11]

$9990 \mathrm{OH} \quad$ High-energy laser interaction with solids: a laser safety perspective [9990-12]

9990 ol Neutralization of improvised explosive devices by high-power lasers: research results from the FP7 project ENCOUNTER [9990-21]

9990 0J Laser irradiation effects on thin aluminum plates subjected to surface flow [9990-13]

9990 OK Simulation study of the lethality effect of high-power laser with supersonic air flow [9990-14]

POSTER SESSION

9990 OL Laser-based space debris removal: design guidelines for coherent coupling power transmission [9990-15]

9990 ON The optical waveguide generated by acoustic waves emitted from femtoseconds filaments [9990-17] 


\title{
Authors
}

Numbers in the index correspond to the last two digits of the six-digit citation identifier (CID) article numbering system used in Proceedings of SPIE. The first four digits reflect the volume number. Base 36 numbering is employed for the last two digits and indicates the order of articles within the volume. Numbers start with 00, 01, 02, 03, 04, 05, 06, 07, 08, 09, 0A, 0B...0Z, followed by 10-1Z, 20-2Z, etc.

\author{
Auslender, llya, OF \\ Barmashenko, Boris D., OF \\ Bigotta, S., 03 \\ Châteauneuf, Marc, $\mathrm{OH}$ \\ Chen, Minsun, OG, OJ \\ Cheng, Minshun, OK \\ Cohen, Tom, OF \\ Daigle, Jean-François, $\mathrm{OH}$ \\ Diener, K., 03 \\ Eichhorn, M., 03 \\ Galecki, L., 03 \\ Geiss, L., 03 \\ Han, Gaoce, OD \\ Huang, Wei, OD \\ Ibach, T., 03 \\ Jiang, Houman, OG, OJ \\ Kästel, Jürgen, OL \\ Knize, R. J., OC \\ Kosareva, O. G., ON \\ Lebiush, Eyal, $\mathrm{OF}$ \\ Lexow, B., 01 \\ Li, Hui, OD \\ Li, Zhiyong, OD \\ Lueck, M., Ol \\ Osterholz, J., Ol \\ Pankratov, V. V., ON \\ Panov, N. A., ON \\ Peng, Xin, OJ, OK \\ Pudo, Dominik, $\mathrm{OH}$ \\ Rosenwaks, Salman, OF \\ Rotondaro, M. D., OC \\ Scharf, H., 03 \\ Schöner, J., 03 \\ Shaffer, M. K., OC \\ Shipilo, D. E., ON \\ Speiser, Jochen, OL \\ Takehisa, K., OE \\ Tan, Rongqing, OD \\ Théberge, Francis, $\mathrm{OH}$ \\ Vincent, G., 03 \\ von Salisch, M., 03 \\ Wickert, M., Ol \\ Yandulsky, M. M., ON \\ Zhang, Tianyu, OG \\ Zhang, Xiangyu, OG \\ Zhao, Guomin, OJ, OK \\ Zhdanov, B. V., OC
}




\title{
Conference Committee
}

\author{
Symposium Chairs \\ David H. Titterton, United Kingdom Defence Academy \\ (United Kingdom) \\ Symposium Co-chairs
}

Ric Schleijpen, TNO Defence, Security and Safety (Netherlands)

Karin Stein, Fraunhofer-Institut für Optronik, Systemtechnik und Bildauswertung (Germany)

Stuart S. Duncan, Leonardo-Finmeccanica (United Kingdom)

Conference Chairs

Harro Ackermann, High Energy Laser Joint Technology Office

(United States)

Willy L. Bohn, BohnLaser Consult (Germany)

David H. Titterton, UK Defence Academy (United Kingdom)

Session Chairs

1 Novel Laser Systems and Power Scaling

Willy L. Bohn, BohnLaser Consult (Germany)

2 Fiber Lasers and Beam Scaling

Martin C. Richardson, CREOL, The College of Optics and Photonics, University of Central Florida (United States)

3 Diode Pumped Alkali Lasers and Other Advanced Gas Lasers

Boris V. Zhdanov, U.S. Air Force Academy (United States)

4 Laser Interaction and Damage

David H. Titterton, UK Defence Academy (United Kingdom) 